\title{
Mentoring Needs of pre-Service Teachers During Teaching Practice. A Case Study at a South African University
}

\author{
Dr. PJH Heeralal \\ University of South Africa \\ College of Education \\ Department of Science \&Technology Education \\ P.O.Box 392, Unisa \\ South Africa, 0003 \\ e-mail: heerapj@unisa.ac.za
}

\section{Doi:10.5901/jesr.2014.v4n1p511}

\begin{abstract}
Mentoring of students during teacher training is an important component in developing competent teachers. Different student have different needs and hence need to be mentored differently. The manner in which it is done will determine how successful a teacher will be in performing his/her duties and responsibilities when the teacher takes up a full time teaching post at a school. Mentoring has to be done in a way that meets the needs of the student and has an impact on the student and his future career. Often, on entering the teaching profession, the novice teacher will not be inducted into the profession by means of an induction program at the school, but will be required to commence with the normal duties and responsibilities. The teacher will need to "find his footing" on his own and this can lead to frustration, stress and disillusionment on the part of the teacher. However, if the student, while in training, receives mentorship in a structured and meaningful way, it will assist in easing the trauma that the novice teacher experiences on entering the teaching profession.Data was gathered from student teachers by means of a structured questionnaire to explore student's teachers mentoring needs. The data was analysed with the view of identifying the mentoring need of pre-service teachers so that mentors assist student teachers in meeting their needs and overcoming some of the challenges that they may face on entering the teaching profession.
\end{abstract}

Key words: mentoring needs, pre-service teachers, teaching practice

\section{Introduction}

Pre-service teachers receive training in academic and practical aspects of teaching. The practical aspect of their training involves teaching at a school for a period of time. During this time pre-service teachers are attached to a host teacher who acts as a mentor to the student. In order to provide effective mentoring during practice teaching, mentor teachers need to identify the areas that their mentees need the greatest amount of assistance in developing their teaching capabilities. The purpose of this paper is to identify these areas, so that mentor teachers are aware of the mentoring needs of the students and can offer greater assistance and guidance to the mentees in these areas, thus preparing them more adequately to join the teaching profession. A mentor according to Singh, Bains \& Vinnicombe, 2002.p 391, is an individual with advanced experience and knowledge who is committed to providing upward support and mobility to his/her protégés' career. Smith, Howard, Harrington, 2005, p.33, describes a mentor as a more senior person, who takes an interest in sponsorship of the career of a more junior person. A mentor thus plays an important role in 'professional development and career progress' (Tepper, 1995) of the in-service teachers.

In the context of pre-service teacher training, Tomlinson $(1995, p .7)$ defines mentoring as 'assisting studentsteachers to learn how to teach in a school based setting. According to this definition Hobson $(2002$, p.1) states that mentoring in in-service training of teachers 'is undertaken not merely by teachers holding the formal title of mentor but also by other teachers whose advise and support may be sought or whose teaching and interactions with pupils may be witnessed by student teachers'. Hobson (2002, p.1) thus argues that all teachers in a school that has student teachers ought to be aware of how to perform the task of effective mentoring of student teachers.

Hobson, (2002) identifies three factors that point to the importance of mentoring in initial teacher training. First, the place of mentoring in initial teacher training has become pivotal since students in postgraduate training courses are required to spend a considerable amount of their course time in schools. Secondly, 'a number of influential theories of 
professional learning also point to the learning potential of having trainee professionals work closely with experienced practitioners, and such theories provide insights into different forms that effective mentoring might take.' (Hobson, 2002). Tharp \& Gallimore, 1998: Wertsch, 1991: Rogoff, 1995, in Hobson, (2002) point out that support for school based mentoring can also be found in Vygotskian and 'socio-cultural' perspectives, which tell us that human activities are rooted in social participation and learned not in isolation but with the assistance of others. The third indicator of the importance of mentoring in pre-service teacher training, according to Hobson are based on the 'conceptions of those who are seeking to become teachers.' Hobson, 2001, in Hobson, (2002), states that student teachers, prior to their actual experience of school-based training, expected school-based mentoring to be pivotal to their learning of teaching. These teachers indicated that it would be valuable to plan lessons with mentors and have mentors observe their teaching and give feedback. According to Hobson, (2002) 'such expectations of the potential value of working with school-based mentors were significantly higher than their expectations of the potential value of other aspects of other aspects' of preservice training provisions. It is therefore important to take into consideration students mentoring needs.

Hudson,(2008) identifies the following mentoring needs amongst pre-service teachers: understanding of system requirements (curriculum, school policies and assessment),writing of lesson plans, articulate pedagogical knowledge (such as teaching strategies, classroom management, motivating students and dealing with unexpected situations and providing direct and detailed feedback about teaching performance. Hudson, (2002), also suggests that mentor provide constructive guidance such as sharing teaching experiences and giving clear advice. Pre-service teachers also require constructive feedback on their teaching methods and more opportunities to teach. Blank and Sinderlar, 1992; Klausmeier, 1994 identify time management as another area that needs attention during mentoring.

Mentors need to be committed to their mentoring role and believe in the potential of the mentee (Anglin, Sanchez \& Ballou, 2002; Sinclair, 2003). Since the mentor has to has to provide information and assistance to the pre-service teacher in broad spectrum of areas, Klausmeier, (1994), contend that the 'mentor's ability to adapt to different situations is critical' in providing effective mentoring.

\section{Methodology}

The study aims to obtain pre-service students mentoring need during practice teaching hence the researcher opted for a quantitative study that is descriptive in nature (Leedy \& Ormrad, 2005:94,197). Leedy \& Ormrod (2005) suggest that a survey research refers to almost any form of descriptive, quantitative research. A structured questionnaire was administered to thirty nine (39) final year Bachelor of Education students at a South African university to ascertain students mentoring needs during practice teaching. Students had to indicate, from a list of needs, which areas they would need mentoring in This paper will therefore focus on the data collected from the students to identify the areas of mentoring needs The purpose of identifying the needs was to make mentors aware of which areas in-service teacher were in need of mentoring, so that mentoring activities would be more focussed. It would also give the mentor an opportunity to prepare for specific areas of mentoring, depending on the need of the mentee.

\section{Data collected}

The students were required to indicate the areas in which they required mentoring.

Table 1 indicates the students mentoring needs. Only descriptive statistics were used to analyse data. Percentages were calculated for the various questionnaire items and conclusions were made. The analysis and discussions reflect only the actual responses received from students for the various instrument items.

Analysis of data

Table 1 Mentoring needs of Pre-service Teachers

\begin{tabular}{|l|l|l|}
\hline ASPECT & $\begin{array}{l}\text { Number of students needing } \\
\text { mentoring in this area }\end{array}$ & $\begin{array}{l}\text { Percentage of students needing } \\
\text { mentoring in this area }\end{array}$ \\
\hline Lesson preparation & 33 & 84.6 \\
\hline Lesson presentation & 31 & 79.5 \\
\hline Assessment & 34 & 87.2 \\
\hline Classroom management & 31 & 79.5 \\
\hline Time management & 22 & 56.4 \\
\hline
\end{tabular}




\begin{tabular}{|l|l|l|}
\hline Discipline & 30 & 76.9 \\
\hline Administrative matters & 32 & 82.0 \\
\hline Professional development & 25 & 64.1 \\
\hline Extra and co-curricular activities & 19 & 48.5 \\
\hline Adapting to a school environment & 14 & 35.9 \\
\hline Relationships & 14 & 38.5 \\
\hline Dealing with diversity & 16 & 41.0 \\
\hline Dealing with change & 15 & 38.5 \\
\hline
\end{tabular}

\section{Discussion:}

The data suggests that the of greatest mentoring needs of pre-service teachers lies in the areas of assessment (87.2\%), lesson preparation (84.6\%), administrative matters $(82.0 \%)$, classroom management $(79.5 \%)$, lesson presentation (79.5\%), and discipline (76.9\%). However, the other areas: professional development (64.1\%), time management (56.4\%) and extra and co-curricular activities (48.5\%) also need attention. Dealing with diversity (41.0\%), dealing with change (38.5\%), relationships (38.5\%) and adapting to a school environment, cannot be ignored as areas of need amongst pre-service teachers.

\section{Lesson preparation}

In order to teach an affective lesson a teacher, especially the pre-service teacher, needs to prepare the lesson thoroughly. Preparation of a lesson ought to begin with the identification of a suitable topic for the lesson. The topic for the lesson can be obtained from the contents of the curriculum. The teacher then needs to formulate outcomes for the lesson that are suitable and meet the needs of the learners. Other aspects that need to be considered in preparing a lesson are the previous knowledge of learners, methodology to be used to deliver the lesson, the resources needed, the content knowledge that has to be communicated/taught to learners, assessment of learners, time management, logical lesson development. Guidelines produced by the Department of Education should be consulted as they provide valuable information in assisting the in-service teacher in preparing a lesson. During teaching practice, the in-service teacher must consult with his/her host teacher or mentor for assistance in enhancing the quality of a lesson that is being prepared. Sufficient time needs to be budgeted/allocated for lesson preparation. Underestimation of the time taken to prepare a lesson can be a serious drawback in preparing and presenting a successful lesson.

In preparing a lesson a teacher needs to find out what the learners already know, what the curriculum requirements are, what outcomes need to be achieved, what strategies or method will be used to achieve these outcomes, what new knowledge will be acquired by learners and what assessment strategies will be used to ascertain whether the knowledge has been acquired by the learners, what activities the learners will be involved in and what resources are available.

Novice teachers acquire theoretical knowledge on lesson preparation from various university modules and even get an opportunity to prepare lesson (which they do not teach). During practice teaching they will need to prepare lessons that they will be required to teach to learners. In order to prepare these lessons, the pre-service teacher will need to be guided and mentored by the mentor teacher. The lesson has to be prepared to meet the needs of a specific group of learners. The mentor teacher, being the teacher of this group of learners has a better understanding of their needs and will be able to assist the pre-service teacher in preparing the lesson that addresses the needs of the learners.

\section{Lesson presentation}

It should not be taken for granted that a well prepared lesson will produce the desired result of the achievement of the lesson outcomes. Serious attention has given to lesson presentation. In order to present a lesson a teacher has to adopt a teaching strategy. A teaching strategy, according to Dreckmeyr, (1994,p 67), ' is an extensive teaching plan which includes all the elements of instructional-learning events, such as form, content, classification, principals and aids.' In presenting a lesson, the teacher needs to give careful consideration to the following: explaining the importance and relevance of the lesson and how it links to the previous lesson. The teacher thus needs to draw on the previous knowledge of learners. Generation of interest in the lesson can be achieved through the use of a variety of resources and active involvement of the learners in the lesson. The mentor needs to observe the students lessons and provide feedback to improve lesson presentation. 


\section{Assessment}

Assessment of learners forms an integral part of a teachers responsibilities. Assessment in South African schools is rigorous and often time consuming. Assessment is done according to the national protocol on assessment. Teachers need to be familiar with the procedures set out in this document and perform learner assessment in accordance to it. Because the requirements for assessment changes from time to time it becomes a challenge even for experienced educators to keep up with current requirements. It is an even greater challenge for the pre-service teacher to meets the demands of the assessment system; hence they require mentoring in this aspect more than in any of the other areas. The experienced mentor can share best practices regarding assessment with the pre-service teacher. Interpretation and practical implementation of assessment policies occur in the classroom. The mentor needs to "show the student the ropes' of learner assessment. Assessment becomes challenging to the novice teacher because, with every revision or change in curriculum, which has happened quite often in South African since 1996 (Outcomes Based Education (OBE), revised National Curriculum Statement (RNCS), National Curriculum Statement (NCS) and Curriculum and Policy Assessment Statement (CAPS), the teacher has to adapt, change and implement assessment policies and procedures as per the requirements of the curriculum. Even experienced teachers find it difficult to cope with the ever changing demands and requirements of learner assessment. Hence the novice or pre-service teacher will need guidance and assistance in the area of learner assessment.

\section{Classroom management}

Managing a classroom is a complex process and a daunting task for a novice pre-service teacher. In order to effectively manage a class, the pre-service teacher needs to be eased into this process. Thus during practice teaching, the mentee, initially needs the mentor to be present in the classroom to oversee how the mentee is coping with handling the class. As the mentee gains confidence, the mentor may gradually withdraw from the classroom, allowing the mentee to manage the classroom on his/her own. Classroom management involves amongst other things the management of: classroom space, relationships and interactions, control, authority, discipline, system of rules and procedures, safety of learners and curriculum issues. To manage classroom well requires dedication, commitment and effort. Therefore the role of the mentor, in classroom management, is crucial in developing the in-service teacher's skills.

\section{Discipline}

With the abolition of corporal punishment in schools the maintenance of discipline has become a contentious issue in education circles. Maintaining discipline in the classroom is crucial for effective teaching and learning to take place. Learner doesn't see the pre-service teacher as a fully fledged teacher and thus seem not to afford the student the same status as their own teacher. Hence student teachers experience difficulty in maintaining discipline in the classroom. Mentor teachers therefore need to impress on their class the importance of affording the student teacher the same degree of co-operation that they afford to their regular or own teacher. Student teachers also need to reflect on their own degree of assertiveness in maintaining discipline in the classroom. They need to develop techniques of maintaining discipline by observing how other teachers go about maintaining discipline.

\section{Administrative matters}

One of the core areas of responsibility of a teacher is to attend to administrative matters. This may include the keeping of records. Teachers are required to compile a file that contains essentials records of lessons that they have planned learner records, and assessment records. The essential requirements of a teacher file according to the DOE are:

- annual work schedule

- assessment schedule

- formal assessment tasks and memoranda

- indication of textbooks and other resources to be used

- record sheets containing learners; marks for each formal assessment task

- any intervention that is planned by the teacher to assist learners, especially those who are experiencing barriers to learning. 
An educator needs to maintain all records pertaining to learners under their care (Joubert \& Prinsloo, 2009, P.198). These records need to be maintained as per their specific job descriptions. In order to develop administrative skills in inservice teachers, the mentor teacher needs to provide opportunities for the student to perform administrative tasks that the mentor is engaged in. Performing these tasks will enable the student to develop his/her administrative competence.

\section{Professional development}

Professional development is the extent to which a teacher acquires further and new skills and expertise in, not only in his/her own learning area but more particularly in educational thinking, administration, management, vocational and/technical areas.(PAM Chapter 3). The mentor needs to provide the pre-service with opportunities to become familiar with new developments, thinking and fresh ideas in education. This can be achieved by allowing pre-service teachers to attend workshops and seminars organized by the department of education while the student is doing his/her practice teaching. This will motivate and empower students to get involved in professional development.

\section{Conclusion}

Pre-service teachers require the assistance of mentors in lesson preparation, methods of presenting lessons, assessment of learners, administration matters, classroom management, maintenance of discipline and professional development. Teacher education and training intuitions also need to take note of these areas of need amongst preservice teachers. Mentors ought to be provided with training so that they can be of assistance to the pre-service teachers in these areas.

\section{References:}

Anglin, M., Sanchez, W., \& Ballou, M. (2002). Mentoring and relational mutuality: protégés' perspective. Journal of Humanistic Counseling, Education and Development, 4(1), 87.

Blank, M. A., \& Sindelar, N. (1992). Mentoring as professional development: Fromtheory to practice. The Clearing House, 66(1),22-27 Hudson, P.B. \& Nguyen, Thi. H. (2008) What do preservice EFL teachers expect from their mentors? In Australian Association of Research in Education (AARE) Conference 2008, 30th November - 4th December, 2008, Brisbane.

Hobson, A.J. (2001). Postgraduate history specialists' perspectives on their initial teacher preparation: preconceptions, experiences and evaluations, thesis, School of Education, University of Leeds.

Hobson ,J.A. (2002). Students Teachers' perceptions of School-based Mentoring in Initial Teacher Training (ITT). Mentoring and Teaching, 10(1)

Hobson, A. J. (2002). Student teachers' perceptions of school-based mentoring in initial teacher. Mentoring \& Tutoring: Partnership in Learning, 10(1), 5-20

Joubert, H.J. \& Prinsloo, I.J. (2009), The law of education in South Africa Van Schaik Publishers p.198

Klausmeie, R.L. Jr. Responsibilities and Strategies of Successful Mentors The Clearing House Vol. 68, No. 1 (Sep. - Oct., 1994), pp. 2729

Leedy ,P., Ormrod, N.J. (2005), Practical research: planning and design , Prentice Hill, p. 197

Rogoff, B. 1995. Observing socio-cultural activity on three planes: participatory appropriation, guided participation and apprenticeship, in Wertsch JV, Del Rio P \& Alvarez A (Eds) Sociocultural Studies of Mind. Cambridge: Cambridge University Press.

Sinclair, C. (2003). Mentoring online about mentoring possibilities and practices. Mentoring and Tutoring: Partnership in Learning, 11(1), 79-94.

Singh, V., Bains, D. \& Vinnicombe, S. (2002). Informal mentoring as an orgisational resource. Long range Planning 35 p 391.

Smith, WJ, Howard, J.T. \& Harrington, K.V. (2005). Essential formal mentor characteristics and functions in governmental and nongovernmental organizations from the program administrator's and the mentor's perspective. Public Personnel Management, 34: 31-58.

Tepper, B.J. (1995). Upward maintenance tactics in supervisory mentoring and non-mentoring relationships. Academy of Management Journal, 38(4), 1191-1205.

Tharp, R. G. \& Gallimore, R. (1998). Rousing Minds to life. Cambridge: Cambridge University Press.

Tomlinson, P.D. (1995), Understanding Mentoring: Reflective strategies for school based teacher preparation. Buckingham: Open University Press.

Wertsch, J.V. (1991). A sociocultural approach to socially shared cognition, in Resnick L.B, Levine, J.M. \& Teasley, S.D. (Eds) Perspectives on Socially Shared Cognition. Washington, DC: American Psychology Association 
